\title{
The Effects of the Powers of Justice of Peace on the Criminal Justice System of Pakistan (A Shift of Change or Stumbling Block?)
}

Shahzada Aamir Mushtaq

PhD Scholar, School of Law and Economics, Zhengzhou University, Henan, Mainland China

\author{
DOI: $10.36348 /$ sijlcj.2020.v03i06.008 $\quad$ | Received: 29.05.2020 | Accepted: 05.06.2020 | Published: 14.06 .2020 \\ *Corresponding author: Shahzada Aamir Mushtaq
}

\section{Abstract}

The legislators augmented the provision of section (22-A), in Criminal Procedure Code in order to provide the alternate platform to the man in the street against the highhandedness of police officials. The powers vested with the Justice of Peace aims to cross check the act of the station house officer whether he has acted legally or illegally under section 154, of criminal procedure code. The situation further aggravated when it becomes the establish practice of every Tom, Dick, and Harry to seek remedy under the shadow of the office of justice of peace. The mechanism outlined in the police order 2002, for the redressal of grievances has been failed. Without putting into operation the departmental hierarchy of police, the powers of Justice of Peace pushed the layman on the horns of a dilemma. The Supreme Court has broken the ice and advanced the line of action in order to address the procedure for the registration of complaints and investigations within the parameters of police order 2002 and ultimately cut this gordian knot. The present study was focus on the analysis of adverse effects of the powers of Justice of Peace on the criminal justice system by explaining the puzzling fact that why Bar councils boycott the turning initiative decided by the Pakistani supreme court in the form of precedent. The nature of administrative power possesses by two offices simultaneously and its adverse effects on the functioning of the criminal justice system. The parliament should play its pivotal role to embrace the proposed reforms from judiciary and national judicial institutions with the high head. A dedicated political will is required to bring new major reforms in order to meet emerging challenges in the criminal justice system instead of to left the room empty for judicature to weather the storm. Some recommendations after analyzing its long-lasting effects on the criminal justice system are also proposed.

Keywords: Justice of Peace, Criminal Justice System, First Information Report, Complaints, Investigation.

Copyright @ 2020: This is an open-access article distributed under the terms of the Creative Commons Attribution license which permits unrestricted use, distribution, and reproduction in any medium for non-commercial use (NonCommercial, or CC-BY-NC) provided the original author and source are credited.

\section{INTRODUCTION}

At the time of inception of Pakistan, congenital functional system of criminal justice which established and ensured the law and order in the newly emerged state until the necessary amendments have taken place. The weak democratic system in Pakistan represent the state as house of cards as Pakistan become enmeshed in fabricated matters due to which the justice system weakened and the homeland had paid a dense cost in term of virtual eradication of essential structure of criminal justice system.

Moreover, as the codes were not rewritten to discuss the challenges offered by emerging world, the edifice established by the law of the land were placed under the control of the political elites in order to secure their personal dominance [1]. The perusal of the Criminal Procedure Code (Cr.P. C.) evident that the role of magistrates is very pivotal for conducting through investigation and look after the function of police [2].

In the era of British rule in Sub-Continent along with other laws/ legislation the historic Code of Criminal Procedure was promulgated in the year of 1898, with forthwith effect [3]. The provision of Section 22 of the Code of 1898 introduced the institution of the Justice of Peace. Then Governor General of British India was vested the powers to appoint persons as the justice of the peace for the particular area subject to its administration, the Governor-General, the Governors, the lieutenant Governors, the chief commissioner, the council's members and the High court judges as Ex-officio Justice of the Peace, Session Judges and the District Magistrates were EX-officio Justice of Peace within their territories administered by the concerned local government [4]. 
After the partition in sub-continent in 1947 the Criminal Procedure Code remains intact with adoptable changes in it and the provisions of section 22, Cr.P.C. underwent some minor changes at different times, occasions and ultimately through the law reforms ordinance no XII of 1972 the said section was reconstituted [5]. The same ordinance empowers the provincial Government to appoint justices of the peace within the areas under their respective control and augmented to the code of criminal procedure the provisions of two new sections namely section 22-A and 22-B, which conferred certain specific powers on the Justice of Peace and also outlined their duties. After thirty (30) years in 2002 the law reforms had been revisited and new provisions were inserted through the ordinance no CXXXI of 2002. The said ordinance of 2002 promulgated on 21 Nov. 2002 stripped the judges of the High Court of their status of the Ex-Officio justice of peace which they had enjoyed for more than century. The provisions of section 22-A relates to the powers of Justice of Peace and Sec. 22-B deals with its duties [6]. These new provisions in the justice system of Pakistan create a new forum for every layman for the registration of their criminal case if the police officials refused to do it, although under section 154 (Cr. P. C.), it is the statutory duty of the station house officer (S.H.O.) to register the complaint of the complainant if the information conveyed to him disclosed the commission of a cognizable offence irrespective of the veracity of information [7]. The only jurisdiction which can be exercised by sitting justice of the peace to examine the statement reported to him does or does not establish a cognizable infringement and if it does advise the S.H.O. concerned to register the First information report (F.I.R.) of the complainant [8]. The philosophy of the provisions of 22(A) and 22(B) of the Cr.P.C. relates to the authority of the Justice of Peace and an intervention of Justice of Peace is required by both the said sections when there is complaint in respect to law and order situation or any mala fide act on the part of police officials [9].

Justice of Peace (J.O.P.) in his official capacity must keep it in mind that the authority used by him under section (22-A) of Cr.P.C. was nor extra neither lay over effect on the authority of the judicial and executive which had been explicitly dedicated to those authorities maintaining a particular subject in issue. Being an administrative authority, it could only go through the omission committed by police and issue direction towards them to discharge their duties in accordance with law and not to over through it except in necessary situation. Prior to the amendment of subsection (6) to section (22-A) of Cr.P.C. the consistent view of the constitutional courts had been that it would not interfere the process of investigation, so closely to suffocate the theme contained by the Cr.P.C [10].
The fundamental theme of these provisions was to address and eliminate the miseries of the man in the street and to maintain the peace and public tranquility within the society and to keep the people safe from the undue influence of police authorities and make sure that the police officials are acting in line with established procedure. Anybody who has violated the law of the land, he must be treated strictly in accordance with law if the police authorities has committed neglect, failure, excess or any highhandedness has been proved on part of the police against the citizens of Pakistan then the Justice of Peace would issue appropriate directions under section (22A), and (22-B), Cr.P.C. against the culprits to register F.I.R. [11].

The history of the powers and functions of the Justice of Peace can be traced back to the Justice of Peace Act of 1361 of England. The fundamental nature of their duties was to maintain the law and order and prevention of breach of peace. In England and Wales a magistrate (who is empowered with the powers of justice of peace) is appointed on behalf of the crown to keep the peace within a specific district. These magistrates have been delegated the powers to deal with minor criminal matters and proceed to send more serious cases to a higher court for disposition [12]. In England and Wales almost 2700 justices of the peace, half of them are women. In Australia the basic function of the Justice of Peace is to authenticate the execution of documents. In the United States justices of peace are appointed to sit on the lowest courts to hear minor civil and petty criminal cases like issue warrants, deal with petty offences and hold inquests [13].

The Object of section 22(A), Cr.P.C. is only that if a grievance is voiced with regard to nonregistration of F.I.R in a cognizable offence Justice of Peace in terms of said section can only direct / suggest as to whether in terms of section 154, Cr.P.C. the S.H.O has acted legally or illegally, and in case S.H.O had refused to act whether his inaction is justified. Justice of the peace under no provision of law can direct or even observe with regard to the nature of the offence, commission of the offence or addition or deletion of the relevant sections as the same exclusively falls within the jurisdiction of either investigation officer or of the Trail court at the time of framing charge [14].

The intention of the legislature at the time of augmentation of these provisions into the code of criminal procedure was to condense the interventionist role of the elites in the criminal justice system of Pakistan [15]. Every layman might be deprived from the enforcement of their fundamental rights and police officials may refuse to perform their obligations as laid down in section (154) of Cr.P.C consequently aggrieved would suffer irreparable loss. It is also an axiomatic fact that police officials has misused their powers while lodging FIR, so through these provisions a check was 
created to look after the role of the police authorities and if any excess or failure has been committed by police to issue the directions to act strictly in accordance with law [16].

The powers and functions of the Justice of Peace are administrative but not judicial in character and superior courts explicitly declares it that the office of the Justice of Peace is not a court as envisaged in section 6 of Cr.P.C [17]. In this context the role of a justice of the peace in Pakistan is entirely different from the role played by the justices of piece in the United States of America and United Kingdom where only judicial role has been assigned to them to dispose of the petty civil and criminal matters through the act of the legislation [18].

\section{The Theme of section (22-A) of Cr.P.C}

The ultimate goal of this provision is to cut down the mis-use of authority by police officers in discharging their lawful obligations as stated in the judgment of Supreme Court of Pakistan that 'once the application with respect to the occurrence of a cognizable discourtesy is communicated to police the police is duty bound to register a case and in case of refusal or resorting to delaying tactics' the aggrieved person is well within his rights to approach the justice of the peace under section 22(A), Cr.P.C. with a prayer for registration of the case, whenever the justice of the peace would come to the conclusion that a cognizable offence is discernible from the data available on the record he could pass an order even in the absence of complainant. Non issuance of notice to accused is not fatal to the registration of the case [19].

\section{The Magisterial Check on Police Functionaries}

This procedural law efficaciously enabled the magistrates to play their obligatory role in the process of police investigation in order to counter check the heinousness pledged by the police. Furthermore, chapter 14 of Cr.P.C. elaborates the function of the magistrates by establishing a smooth balance of inadvertence. To conduct the investigation of a noncognizable umbrage the permission of magistrates is irremissible under section 155 of Cr.P.C. the provisions of section 156 (3) of the Cr.P.C. explains that any magistrates who is empowered under section 190 of the Cr.P.C. may order the police to inquire the matters relating to cognizable infringement with in his jurisdiction. Every investigation consists of 3 stages namely the administrative phase, executive phase and lastly judicial phase in which in the investigation officer reports the courts about the occurrence of any offence and evidences collected by him.

The code of criminal procedure also contained an effective check on the functions of the police authorities [2]. This basic law has provided a delicately balance that defines the role of the magistracy in the investigation without its direct involvement in the process. For instance, chapter XIV of the Cr.P.C defines the role of the concerned magistrate by creating a fine balance of oversight and soft intervention in the process. For the investigation of a non-cognizable offence, the permission of a magistrate is mandatory under section 155 Cr.P.C. Section 156(3) holds that a magistrate empowered under section 190 can order a police officer to investigate a cognizable offence and under section 157 it is binding for the police officer to send to the magistrate concerned a report of any information regarding the commission of a cognizable offence. Similarly, under section 158 , the investigating officer has to send the reports of every case investigated by him under section 157 to the magistrate for his perusal [2].

In the light of the judgment of the Supreme Court of Pakistan " Police refusing to register FIR, petitioner has adequate remedy under section 22-A(6), Cr.P.C. to approach Magistrate for exercise of power under section $156(3)$, Cr.P.C or by filing a direct complaint under section 200, Cr.P.C., petitioner can also approach District and Session Judge as Ex-Officio Justice of Peace seeking direction for police to register case, adequate remedy being available, provisions of Article 199 of the constitution not attracted [28].

\section{Mechanism for Registration of FIR in the Code of Criminal Procedure}

It is very explicitly stated under section 154 of the code that when any citizen is aggrieved against the assault of any person he then without any delay approached the police station concerned and inform the station house officer about the commission of alleged offence either orally or in writing by which S.H.O. is bound by law to reduce into writing and necessarily be read over to the informant and shall be entered in the relevant register to be kept by such officer as the provincial Government determine it. About the procedure of registration of F.I.R. the Supreme Court of Pakistan explains it in the following manner, police enjoys no jurisdiction to cause delay in registration of the case and under the law is bound to act accordingly enabling the machinery of law to come into play as soon as this possible and if first information report is registered without any delay, it can help the investigation agency in completing the process of investigation expeditiously, it is advise-able that the provisions of section 154, of the code of criminal procedure read with rule 24(5) of the police rules 1934 be adhered to strictly. There should not be any negligence in recording the F.I.R. and supplying copies to the concerned quarters because departure from the mandatory provisions of law creates a room to doubt the truthfulness of the allegation against the accused nominated in the F.I.R [20].

Another view of the court is that section 154 of Cr.P.C. is obligatory and pre-emptory in nature. S.H.O. has no option but to record statement of complainant in 
relevant register if it discloses the commission of a cognizable offence. If he finds that the occurrence reported does not amount to any cognizable offence, he has to record a report under section 155 of Cr.P.C. The omission to comply with the provision of section 154 , is liable to penal as well as disciplinary action under the relevant rules [21].

\section{Impact of Police Order 2002 on Criminal Justice System}

The police order 2002 was implemented on $14^{\text {th }}$ of August 2002 and put back the police Act of 1861. The basic purpose of this order was to reform the institution of police and re-establish the criminal justice system according to the law of the land and democratic aspirations of the people of Pakistan. Maintenance of public order and establishment of efficacious police service was the core theme of the said ordinance. The numerous independent bodies and institutions were proposed to be established in order to create a perfect system of check and balances on police officials and to make them accountable for their professional misconduct. The old police Act of 1861 was incapable to address the emerging changes which have taken place in the criminal justice system of Pakistan. In fact, the police Act of 1861 had obturate the brass of the rule of law and consequently feebleminded the development of a professional system of policing. The police order 2002 was influenced from the Japanese Model of Community Policing to create social harmony between police officials and the general public and further by minimizing the political influence in police department. It aims to refine the role of the police, their attitudes, duties and responsibilities and to promote amity and deals the common man with due decorum and courtesy. A comprehensive complaint handling system was introduced in the police order under the domain of District Public Safety Commission and Police Complaints Commission [22].

\section{Nature of Powers of the Justice of Peace}

The powers conferred upon the Justice of Peace is not judicial in nature but only has administrative effect because this fact is also recognized by the superior courts of Pakistan that office of the justice of the peace is not a court as envisaged under section 6 of the code of criminal procedure [12]. It is very contemplative if the nature of the powers is not judicial then what would be the effect of it? Even it would not be taken as the order of the court as the definition of courts has been explained in section 6 of the code of criminal procedure.

It has also been observed from different angel in another judgment by the courts that powers of the justice of the peace are very limited which have been given to aid, assist and authorize the criminal jurisdiction system, said powers are neither supervisory nor judicial but are administrative and ministerial in nature [23]. Powers are to be exercised within the framework of section 22-A of the code of criminal procedure and the duties are to be performed within the framework of section 22-B. functions and directions of the Ex-Officio Justice of Peace could neither be challenged under sections 435/439 of the code of criminal procedure nor under Article 199 of the constitution and the same could be challenged only under section 561-A, Cr.P.C. [24].

The powers of the change of investigation by the Justice of Peace under section 22-A(6) of the code of criminal procedure is contradictory with the mandate given to the Superintendent of Police (S.P.) investigation under article 18(6)[29] of the Police Order 2002, who also conferred the statutory powers to change the investigation and make sound order in this respect. The nature of the powers regarding the change of investigation of both the J.O.P and S.P. investigation is administrative in character but it would be more appropriate to follow the departmental hierarchy for the redressal of grievances as outlined in Police Order 2002 rather to invoke the authority of Justice of Peace. This exercise will make the police officials accountable for their conduct within the department and would also affect their repute and promotions accordingly. The departmental mechanism must be put into motion. The parallel jurisdiction of both offices puts the man in the street on the horns of dilemma.

The application for the change and transfer of investigation could be sited to the police officials according to the procedure prescribed in article 18 (6) of Police Order 2002. For the discarding of the complaints on merits, there is no jurisdiction of Justice of Peace to precede the request for transfer and change of investigation to the police concerned irrespective of the scheme mentioned in the said police order. It is under the domain of Justice of Peace to put in motion the departmental mechanism for the transfer and change of investigation under article 18 sub clauses 6 of the police order 2002, when his office is approached and departmental hierarchy has not acted in line with its vested mandate [25].

\section{Jurisdictional effect of High Court}

High court under article 199 of the constitution of Pakistan 1973, and section 561-A of the code of criminal procedure is empowered to review or set aside the order passed under section 22-A, of CR.P.C. But such power can only be exercised if lower court had not applied its judicial mind or had overlooked some material aspect of the case [26].

In another judgment it was observed that on refusal of the police to register F.I.R. in a cognizable case the adequate remedies available to the aggrieved parties are firstly by approaching the session judge, ExOfficio Justice of Peace for exercise of powers under section 22-A(6) of the code of criminal procedure, Secondly, by approaching the magistrate for exercise of 
power under section 156(3) of the code of criminal procedure and lastly by filing a direct complaint under section 200 of the Cr.P.C., invoking of the writ jurisdiction in the presence of the adequate remedy being available is not desire of law [27].

\section{Proposals for Reforms}

The Police Order 2002, which was still to be fully implemented, was massively amended in November 2004, and 54 articles were thoroughly amended which is axiomatic that the political elites were annoyed on losing their control on police as a result of institutional checks and balances outlined in the police order 2002. It is an undeniable fact that it is presumed that the will of the political leadership is more sacred then the provisions of law. Following are some of the proposals for reforms in the existing criminal justice system,

1. Digitalizing community policing awareness programs should be launched in order to convey the theme that the institution of police will work as problem solving approach rather than to rule the lay-man as a police force and closer community police interactions should be activated so that the confidence of the common man on the police force may be restored and it will paved the way in the reduction of the crimes.

2. The District public safety and police complaints commissions shall be immediately established and their performance be monitored. The lack of these two institutions has made the police more powerful which is against the spirit of police order 2002. There is no executive control over the district police machinery although the Justice of Peace has also executive powers under section 22-A of the code of criminal procedure but that would not make the police accountable. If these two offices have been restored, they will work as an alternate platform for the aggrieved persons and ensure compliance strictly of their orders and this would also abridge the burden of the district judiciary.

3. The provincial and national public safety commissions could also be established in order to monitor the performance of the district and police complaints commissions as a double check. The provincial commission shall take steps to disengage the police from unlawful activities and determine the structure of promotion on the recommendations of district public safety commission and criminal justice co-ordination committee. In this way the police officials will remain under the direct check of two independent commissions and most probably not misuse their authority for which section 22-A, of the code of criminal procedure has augmented. The provincial commission shall also observe the investigation process at district level and proposed recommendations for legislation before the national public safety commission.

4. The autocratic style of governance by politicians is against the spirit of the code of criminal procedure and the police order 2002 due to which the social milieu between common man and police has accelerated. The criminal justice co-ordination committee as was suggested in the police order should be activated in each district. This committee will review the operation of the criminal justice system in the district and will also play the role of bridge between police and district judiciary by which the efficiency of the respective departments would have been improved. The senior most lawyers of the district could be given proper representation in the committee who will guide the general public for the enforcement of their rights.

5. The powers of the justice of the peace under section 22-A, Cr.P.C. for the change of investigation shall be abolished and the mechanism against the transfer of investigation as provided under article 18(6) of the police order 2002 could be fully observed and implemented and investigation branch should play their pivotal role in this respect. This exercise will make police officials expert and they will use their potential capabilities in investigations which resultantly condense the apprehension of lacuna of laws in police investigations. The parallel administrative power for the change of investigation possesses by the J.O.P and S.P. investigation has not been exercised properly by both the offices and the fundamental problems remains between the devil and the deep sea which further aggravated the already pregnant situation.

6. The mandate given to the police under section 155 of the code of criminal procedure and under section 169 of the same code must not be arbitrarily exercised. The investigation officer who prepare report under section 155 of the Cr.P.C., whether cognizable offence has been made out or not and report under section 169 of the code of criminal procedure acquit the accused from the allegations due to the lack of evidences must be cross checked by the magistrate or S.P. investigation. If the investigating officer acted dishonestly under these two provisions and founds guilty of professional misconduct he should be removed from service forthwith. If the powers given to the investigation officers under these sections will remains unchecked would be a stigma on criminal justice system and consequently paralyzed the very foundations of police 
department who's integrity has yet to be established.

7. The principle laid down by the Supreme Court of Pakistan in his historic judgment[18], provides complete mechanism within the police department for the redressal of grievances. This principle shall be made obligatory for every complainant and to put the departmental scheme into motion by which the police institution would be functionalized accordingly. But it becomes habitual practice of every complainant that without observing the scheme contained by the said judgment directly knocked the door of Justice of Peace who in response to that referred the case again to senior police officials or either dismissed the petition. This judgment provides alternate platform for the disposal of complaints in the form of three tiers police redressal complaint system which is in consonance with the spirit of police order 2002.

8. The National Judicial Policy Making Committee shall review the various provisions of criminal law and their effects on the criminal justice system after every ten years and then in collaboration with the law and justice commission could propose new legislation before the parliament for its enactment. Lack of judicial reforms is the main impediment towards the establishment of rule of law.

9. The powers of the justice of the peace under section 22-A, Cr.P.C. should be transferred to the magistrate and the offences must be classified in which these provisions are specifically applicable like the United States of America and United Kingdom. The nature of the offences must be categorized and these provisions could not be randomly applicable except certain offences which mainly disturb the public peace and tranquility.

10. The role of the ombudsmen should be extended at the district level who would monitor the progress of public offices particularly the police and on monthly basis submit its report to the provincial government concerned. The provincial government then in the light of the progress report makes every public office holder accountable who found guilty.

\section{CONCLUSION}

Mere vesting of powers without fruitful results causes irreparable loss to the justice system. The National Judicial Policy Making Committee shall impetus the reform process in the criminal justice system. The legislative assembly should also ameliorate the justice system and tried to avoid this common exigency. The edifice of the criminal justice system is very elusive which need palatial reforms in the twinkling of an eye. The role of the lawyer's community is beside the mark and even amounts to aberration. The core issue is to facilitate the man in the street and all stakeholders including Bar Councils Associations could support the reforms with a high head. The police order 2002, which aims to bring reforms for police structure, shall be fully restored with its true spirit rather than to become a stumbling block. The parameters determine by the supreme court of Pakistan in his judgment to follow the departmental procedure shall be given weightage for consideration. The police institution is paralyzed due to interventionist approach by elite class which endangers the very foundations of the criminal justice system.

\section{REFERENCES}

1. Cheema, G. S. (2005). Building democratic institutions: Governance Reform in Developing Countries. Kumarian Press.

2. Shigri, A.A. (2017). Judiciary \& investigation, The Daily DAWN June $19^{\text {th }} 2017$, [Online] Available at: https://www.dawn.com/news/1340374

3. Siddique, O. (2013). Pakistan's experience with formal law: an alien justice. Cambridge university press.

4. Misra, B. B. (1963). Efforts for Administrative Reforms Before Independence. Indian Journal of Public Administration, 9(3), 311-335.

5. Munir, M. A. (2018). Alternative Dispute Resolution (Adr) in Trial Courts of Pakistan: A Practical Approach towards New Era of Timely Justice as a Means of 'Justice for All'.

6. Alfini, J. J., Gupta-Brietzke, S., \& McMartin IV, J. F. (2006). Dealing with Judicial Misconduct in the States: Judicial Independence, Accountability and Reform. S. Tex. L. Rev., 48, 889.

7. Gauhar, N. A. (2014). Honour crimes in Pakistan: unveiling reality and perception. CAMP.

8. Shinwari, N. A. (2015). Understanding the Informal Justice System: Opportunities and possibilities for legal pluralism in Pakistan. CAMP.

9. 2008 MLD 1142

10. Gul, W., \& Others, V. (2010). Zahara Bibi \& others: [2010 P.CR.L.J 45]

11. Abdul, Wahab, V.(2004). Government of Sindh through Secretary, Home Department, Karachi and 2 others: [2004 YLR 2599] (Karachi).

12. Plucknett, T. F. T. (2001). A concise history of the common law. The Lawbook Exchange, Ltd. Police Order 2002

13. Musson, A. (1998). The evolution of English justice: law, politics and society in the fourteenth century. Macmillan International Higher Education.

14. Muhammad, Javed, Khan, V.(2007). Additional Session Judge Multan: [2007 P.Cr.L.J 124]

15. Shah, R. U., Khan, S. U., \& Farid, S. (2014). Causes for Delay in Civil Justice in Lower Courts of Pakistan: A Review. Pakistan Journal of Criminology, 6(1), 47. 
16. Shah, R. U., \& Ahmad, J. Delayed Judicial Processes in Civil Courts and Peacemaking in Pakistan.

17. Mst. Bhaitan, V. (2005). The State \& 3 others: [PLD 2005 Karachi 62]

18. Neubauer, D. W., \& Fradella, H. F. (2018). America's courts and the criminal justice system. Cengage Learning.

19. Tahir, S., Khan, V. (2009). The State \& 4 others: [2009 YLR 436]

20. Imran Ashraf and 7 others v. The State: [2001 SCMR 424]

21. NLR 2000 criminal BWP1
22. ICG Asia Report $N^{\circ} 77$. (2004). Devolution in Pakistan: Reform or Regression? Islamabad/Brussels, 2 March 2004),

23. Hussain, F. (2011). The judicial system of Pakistan (p. 19). Supreme Court of Pakistan.

24. Younas Abbas and Others v. Additional Sessions Judge, Chakwal and Others: [2016 PLD SC 581]

25. Amir, Ali, V. (2008). A.I.G \& Others: [2008 PCR L J 1374]

26. Gul, Muhammad, V. (2012). Dost Muhammad: [2012 YLR 134]

27. Muhammad, Aslam, V. (2004). Additional Session Judge \& Others: [2004 Pcr.L.J.1214]

28. Article 18(6) of the Police Order 2002

29. Article 199 of the Constitution of Pakistan 1973. 